\title{
Peningkatan Ekonomi Masyarakat Melalui Inovasi Produk Olahan Singkong
}

\section{Increasing The Economy District Through The Innovation of Processed Cassava Product}

\author{
Siti Sovia Anwar ${ }^{1}$; Qomaruddin S \\ ${ }_{1}^{1}$ Program Studi Perbankan Syariah Fakultas Ekonomi Islam Universitas Djuanda Bogor, Jl. Tol Ciawi No. 1, \\ Kotak Pos 35 Ciawi, Bogor 16720, email: Soviaanwar1@gmail.com \\ 2Program Studi Ekonomi Syariah, Fakultas Ekonomi Islam, Universitas Djuanda Bogor, Jl. Tol Ciawi No. 1, \\ Kotak Pos 35 Ciawi, Bogor 16720
}

(Diterima: 20-12-2020; Ditelaah: 12-04-2021; Disetujui: 30-10-2021)

\begin{abstract}
Abstrak
Sumber daya alam yang dihasilkan Desa Padamulya sangat melimpah, akan tetapi sumber daya alam yang dimiliki Desa Padamulya belum sepenuhnya dimanfaatkan oleh masyarakatnya, sehingga perlu adanya bimbingan atau pendampingan kepada masyarakat untuk memanfaatkan potensi yang ada. Salah satunya dengan memanfaatkan produk olahan singkong yang dibuat menjadi sebuah makanan dengan harga nilai jual tinggi. Metode yang dilakukan adalah dengan sosialisasi dan pembuatan inovasi produk olahan singkong. Dalam pengolahan produk olahan singkong ini penulis membuat Churros Singkong yang merupakan makanan cemilan enak dan sehat. Setelah dilaksanakan program ini hasil yang didapatkan adalah pengembangan produk olahan singkong lebih kreatif dan inovatif serta masyarakat sekitar lebih memahami cara memanfaatkan sebuah potensi yang ada di sekitar.
\end{abstract}

Kata kunci: Inovasi Produk, Singkong, Pengabdian Masyarakat

\begin{abstract}
The natural resources produced by Padamulya Village are very abundant, but the natural resources owned by Padamulya Village have not been fully utilized by the community, so there is a need for guidance or assistance to the community to exploit the existing potential. One of them is by utilizing processed cassava products that are made into food with high selling price. The method used is the socialization and innovation of cassava processed products. In processing this cassava product, the writer makes cassava churros which is a delicious and healthy snack food. After implementing this program the results obtained are the development of cassava processed products more creative and innovative as well as the surrounding community better understanding how to utilize a potential that is around.
\end{abstract}

Keywords: Cassava, Community Service, Product Innovation

\section{PENDAHULUAN}

Pengabdian mahasiswa kepada masyarakat dilaksanakan untuk memenuhi salah satu tri dharma perguruan tinggi, yakni pengabdian kepada masyarakat yang bersifat lintas disiplin dan sebagai komponen keilmuan, teknologi dan seni secara aplikatif guna membentuk kehidupan masyarakat, utamanya di pedesaan. Bentuk pengabdian tersebut dilaksanakan dengan cara menerapkan ilmu pengetahuan yang sudah diperoleh di perkuliahan kepada masyarakat. Ilmu pengetahuan yang diterapkan adalah ilmu pengetahuan yang diperlukan oleh masyarakat atau yang dapat menjadi solusi bagi permasalahan yang terjadi kehidupan masyarakat. Hal ini dilakukan sebagai wujud rasa kepedulian dan tanggung jawab mahasiswa untuk memajukan bangsa dan negara di 
masa depan. (Lubis, 2004).

Peningkatan perekonomian adalah suatu perubahan jenjang atau perbaikan kondisi dari perekonomian yang lemah kearah perekonomian yang lebih baik atau mengalami kemajuan dari sebelumnya. Pengembangan ekonomi lokal perlu diarahkan untuk mendukung perkembangan sektor-sektor ekonomi yang mempunyai potensi menciptakan kesempatan kerja yang luas dan memiliki prospek yang baik dalam meningkatkan kesejahteraan masyarakat di suatu wilayah. Maka dari itu dengan adanya program ekonomi kreatif yang dilakukan diharapkan mampu merubah sedikit demi sedikit perekonomian masyarakat yang ada di Desa Padamulya dengan mengadakan inovasi baru untuk menjadikan kampungtersebut memiliki mata pencaharian yang lebih beragam dengan memanfaatkan barang bekas yang nantinya dapat bernliai seni dan bernilai jual atau bernilai ekonomis.

Inovasi dalam konteks birokrasi diamanatkan dalam Undang-undang menjadi salah satu pendorong untuk percepatan pembangunan, hal ini sudah terbukti dengan model yang diterapkan di negara maju. Dewasa ini, peningkatan produktivitas tidak hanya bergantung pada pada ilmu pengetahuan dan teknologi melainkan pada ketersediaan sumber daya alam yang dimiliki. Pengembangan kewirausahaan menduduki peran yang sangat strategis makin signifikan. Kita harus mendorong dan mengembangkan kemampuan wirausaha, memanfaatkan peluang bisnis dalam dinamika persaingan global (Prasetyo, 2018)

Desa padamulya adalah desa yang berada dipegunungan dengan kualitas tanah yang subur. Masyarakat kebanyakan adalah seorang petani yang menanam umbiumbian, hasil pertanian tersebut sangat melimpah akan tetapi masyarakat hanya memanfaatkan umbi-umbian tersebut sebatas digoreng dan direbus seperti biasa tanpa inovasi. Jika dapat dikelola dengan baik dan kreatif, singkong tersebut akan menjadi suatu inovasi baru yang memberikan nilai ekonomi bagi masyarakat.

Sumber Daya Alam yang dihasilkan Desa Padamulya sangat melimpah, akan tetapi sumber daya alam yang dimiliki Desa Padamulya belum sepenuhnya dimanfaatkan oleh masyarakatnya, sehingga perlu adanya bimbingan atau pendampingan kepada masyarakat untuk memanfaatkan potensi yang ada. Salah satunya dengan memanfaatkan produk olahan singkong yang dibuat menjadi sebuah makanan dengan harga nilai jual tinggi. Pemilihan program pemanfaatan olahan singkong ini dilakukan karna melihat potensi singkong yang melimpah akan tetapi harga nilai jual singkong tersebut sangat rendah.

Tumbuhnya industri kreatif di Indonesia disebabkan adanya krisis global yang berkepanjangan sehingga memunculkan semangat yang lebih dalam menciptakan, mengkreasikan, dan menginovasikan sesuatu dalam menciptakan ide-ide dan karyakarya yang baru. Arief Johari menyatakan bahwa pertumbuhan industri kreatif yang baik di Indonesia belum mampu memberikan pengaruh yang positif dan signifikan bagi Indonesia salah satu penyebabnya adalah "Manajemen Problem" yaitu suatu pemikiran yang menyebabkan adanya pemikiran bahwa sebuah produk yang dihasilkan hanya untuk konsumsi di dalam negeri sehingga hal inilah menyebabkan bahwa Indonesia 
termasuk pada kategorisasi sebagai negara konsumtif yang potensial secara internasiona. Berdasarkan uraian di atas maka perumusan masalah adalah ekonomi kreatif sebagai suatu solusi mensejahterakan masyarakat dalam meningkatkan tingkat perekonomian.

Dalam hal ini sebuah inovasi sangat diperlukan untuk bisa menciptakan ekonomi kreatif yang di inginkan. Adapun yang dimaksud dengan inovasi adalah sebuah gagasan, produk atau proses yang memiliki potensi untuk digunkan sebagai pemacu daya saing sebuah bangsa, wilayah, industri, organisasi, indivisu atau gabungan dari katagorikatagori ini. Dengan memanfaatkan bahan bekas yang sudah tidak terpakai lalu di inovasikan menjadi sebuah produk yang layak dipasarkan dan layak untuk dihargai.

Singkong (Manihot utillisima) merupakan makanan pokok ketiga setelah padi dan jagung bagi masyarakat Indonesia. Tanaman ini dapat tumbuh sepanjang tahun di daerah tropis dan memiliki daya adaptasi yang tinggi terhadap kondisi berbagai tanah. Tanaman ini memiliki kandungan gizi yang cukup lengkap. Kandungan kimia dan zat gizi pada singkong adalah karbohidrat, lemak, protein, serat makanan, vitamin (B1, C), mineral (Fe, F, Ca), dan zat non gizi, air. Selain itu, umbi singkong mengandung senyawa non gizi tanin (Ariyani, 2017).

Singkong merupakan salah satu tanaman lokal unggulan Jawa Barat. Pada beberapa wilayah, singkong menjadi tanaman yang dominan di pekarangan. Selain itu, pada tanaman padi sebagian petani menumpangsarikan salah satunya yaitu tanaman singkong (Iskandar dkk., 2016). Selama ini pengolahan singkong sebatas pembuatan produk makanan tradisional. Untuk variasi pengolahan belum banyak diketahui oleh masyarakat umum khususnya ibu-ibu rumah tangga. Sehingga pelaksanaan kegiatan pengabdian ini bertujuan memberikan informasi dan keterampilan baru dalam proses pengolahan singkong khususnya kepada ibu-ibu rumah tangga.

\section{METODE PELAKSANAAN}

Penulis melakukan pendampingan ekonomi masyarakat dengan cara membentuk kelompok usaha yang akan mengembangkan potensi sumber daya alam yang ada disekitar wilayah desa Padamulya dengan membuat sebuah inovasi produk olahan singkong.

Adapun lokasi yang dijadikan tempat pelaksanaannya adalah Desa Padamulya, Kecamatan Pasirkuda, Kabupaten Cianjur, Provinsi Jawa Barat. Alasan dipilihnya Desa Padamulya sebagai lokasi sosialisasi dikarenaka desa tersebut merupakan kategori desa tertinggal, sehingga memerlukan banyak bantuan untuk mengembangkannya, terutama bantuan Sumber Daya Manusia (SDM) untuk mengembangkan potensi-potensi desa tersebut.

Kajian teori tersebut untuk mendukung penyusunan program kerja di bidang ekonomi untuk mengatasi permasalah-permasalah ekonomi di Kampung Sirnagalih Desa Padamulya. Berikut program kerja yang dilaksanakan terdapat pada Tabel 1. 
Tabel 1. Program Kerja yang Dilaksanakan

\begin{tabular}{ccrl}
\hline NO & \multicolumn{2}{c}{ Program Kerja } & \multicolumn{2}{c}{ Uraian Program } \\
\hline 1 & Pelatihan & Pembuatan & Pelatihan pembuatan inovasi produk olahan \\
& Produk & Olahan & singkong dapat meningkatkan nilai jual singkong \\
& Singkong & & tersebut, dimana hal ini lah yang mampu membantu \\
& & memanfaatkan potensi yang ada sekaligus \\
& & meningkatkan perekonomian
\end{tabular}

\section{HASIL \& PEMBAHASAN}

Produk yang dihasilkan dari kegiatan program ini adalah pemanfaatan singkong yang diolah dan diberi nama Churros Singkong. Pembuatan produk tersebut bertujuan untuk meningkatkan nilai jual singkong dan mempunyai nilai ekonomi yang tinggi untuk masyarakat Desa Padamulya.

Metode pelaksanaan yang dilakukan penulis berupa program pendampingan ekonomi masyarakat dengan cara membentuk kelompok usaha yang akan mengembangkan potensi sumber daya alam yang ada di sekitar wilayah desa Padamulya salah satunya adalah singkong.

Program produk Churros Singkong yang memanfaatkan umbi-umbian yang melimpah di pedesaan sangat efektif dijadikan sebagai cemilan bahkan oleh-oleh khas daerah tersebut. Dengan adanya pelaksanaan kegiatan pengabdian kepada masyarakat ini bermunculan ide untuk mengembangkan usaha kecil menegah dengan memanfaatkan banyaknya umbi-umbian kemudian dinamakan Churros Singkong dengan pengemasan menarik sehingga dapat menarik perhatian konsumen dan dapat menaikan tingkat perekonomian masyarakat Kampung Sirnagalih.

Pembuatan inovasi produk olahan singkong melalui pelatihan masyarakat kampung Sirnalagih Desa Padmulya dilaksanakan berdasarkan observasi bahwa masyarakat Sirnagalih RT 01 dan 02 ini khususnya untuk ibu-ibu sebanyak $80 \%$ adalah buruh tani dan menanam umbi-umbian di ladangnya.

Adapun perubahan pasca pelaksanaan yang diharapkan adalah sebagai berikut:

Tabel 2. Perubahan yang Diharapkan

\begin{tabular}{cccc}
\hline NO & \multicolumn{1}{c}{ Keterangan } & Pasca Pelaksanaan & \multicolumn{1}{c}{ Pra Pelaksanaan } \\
\hline 1 & $\begin{array}{l}\text { Keterampilan } \\
\text { dalam mengolah } \\
\text { singkong } \\
\text { menjadi sebuah } \\
\text { produk }\end{array}$ & $\begin{array}{l}\text { Belum memiliki } \\
\text { keterampilan }\end{array}$ & $\begin{array}{l}\text { Memiliki keterampilan pengolahan } \\
\text { singkong menjadi produk }\end{array}$ \\
2 & Singkong & $\begin{array}{l}\text { Diolah hanya sebagai } \\
\text { gorengan dan kripik }\end{array}$ & $\begin{array}{l}\text { Singkong diolah menjadi produk } \\
\text { cemilan manis dan memiliki nilai } \\
\text { jual lebih tinggi }\end{array}$ \\
& &
\end{tabular}


3 Nilai jual Nilai jual rendah singkong

4 Pemasaran singkong
Sebatas sebagai singkong pada umumnya
Meningkat karena ada nilai tambah dari produk hasil olahan (jenis produk olahan baru) Dipasarkan lebih luas karena memiliki nilai ekonomis yang tinggi, dapat didistribusikan ke pasar dan supermarket.

\section{Pelaksanaan Program Pendampingan dan Pembuatan Produk Olahan Singkong}

Berikut tahap pelaksanaan program pendampingan dan pembuatan produk olahan singkong.

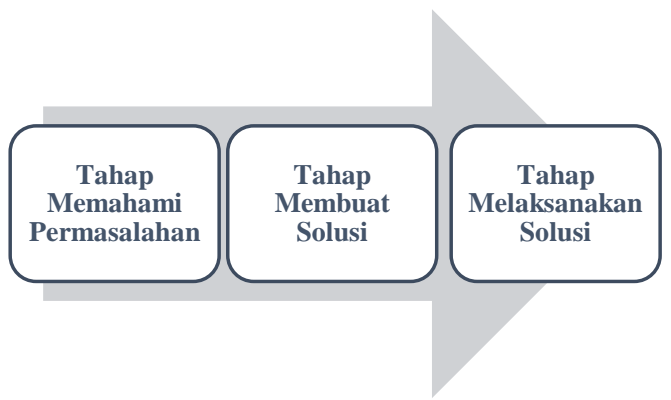

Gambar 1. Tahap Pelaksanaan Penelitian

\section{1) Tahap Memahami Permasalahan}

Dalam tahap ini penulis memahami permasalahan dengan melakukan survei kepada masyarakat sekitar Kp. Sirnagalih Desa Padamulya dalam rangka melakukan identifikasi masalah yang ada. Sehingga penulis dapat merencanakan solusi untuk mengatasi masalah tersebut. Setelah melakukan identifikasi ditemukan bahwa permasalahan yang ada di Desa Padamulya adalah kurangnya pemanfaatan potensi seumber daya dehingga diperlukan pendampingan untuk meningkatkan potensi tersebut.

\section{2) Tahap Membuat Solusi}

Dalam tahap membuat solusi terbagi menjadi beberapa tahap diantaranya :

\section{a. Survei Potensi Sumber Daya Alam (SDA)}

Survei lokasi dilakukan di wilayah Kp. Sirnagalih RT 02 RW 01 Desa Padamulya. Pelaksanaan survei dilakukan dengan cara melihat potensi tanaman singkong yang melimpah dan berada disetiap lahan, kemudian mencari tahu kebiasaan masyarakat dalam memanfaatkan singkong tersebut. Selain itu penulis juga melakukan survei dengan bertanya kepada masyarakat yang memiliki singkong dirumahnya, kebanyakan masyarakat sirnagalih memiliki singkong akan tetapi pengolahannya hanya begitu saja.

Hasil dari survei yang sudah dilakukan ialah, banyaknya singkong yang ada dikampung tersebut, namun tidak di manfaatkan dengan baik. Masyarakat 
memanfaatkan singkong hanya dengan dikukus, digoreng atau dijadikan kripik namun tidak untuk dijual atau diolah menjadi produk yang mempunyai nilai jual tinggi. Harga singkong pun tidak terlalu tinggi, mencapai kisaran harga 1 kg Rp. 5.000.- saja, sehingga masyarakat tidak terlalu memanfaatkan singkong tersebut bahkan singkong hanya dibagikan pada warga lain untuk diberikan secara cuma-cuma. Kemudian munculah ide pembuatan churros singkong dengan tujuan untuk menaikkan harga jual singkong tersebut melalui inovasi produk.

\section{b. Pengembangan Inovasi Produk}

Berdasarkan hasil survei yang dilakukan oleh tim pelaksana, banyak umbi-umbian yang ada diwilayah Padamulya tersebut. Untuk meminimalisir terjadinya kegagalan dalam pembuatan produk maka penulis melakukan percobaan dan pengembangan produk singkong tersebut. Percobaan pembuatan churros singkong ini dilakukan dua kali hingga menemukan hasil yang sempurna dan sesuai dengan apa yang diinginkan.

Selama masa percobaan pembuatan dihasilkan komposisi yang pas dalam pembuatan produk churros singkong yaitu 50g singkong, 10 sendok makan tepung terigu, 2 sendok makan gula, 1 sendok makan mentega, dan satu butir telur. Dengan komposisi yang pas ini produk yang dihasilkan memiliki tekstur lembut denga rasa manis.

\section{c. Membuat Desain Logo dan Kemasan}

Ketika percobaan pembuatan produk berhasil, langkah selanjutnya adalah membuat desain logo dan kemasan yang dilakukan oleh penulis. Pembuatan desain kemasan dibuat dengan semenarik mungkin agar menarik perhatian konsumen. Dalam pemasaran produk, pembuatan nama yang menarik sangat penting untuk produk yang akan disebarluaskan di jangkauan kecil, menengah dan besar. Langkah pembuatan desain produk meliputi:

a. Penulis menggunakan aplikasi canva untuk membuat desain logo produk

b. Mencari gambar churros yang menarik dengan cara browsing.

c. Menentukan format penulisan, font, size dan warna.

d. Mencantumkan logo kelompok dan logo fakultas.

\section{d. Pembelian Bahan Kebutuhan Produk}

Penulis menyediakan kemasan produk yang sudah dibuat kemudian menyiapkan bahan-bahan untuk pembuatan churros singkong. Bahan-bahannya antara lain singkong, terigu, gula, mentega, telur, air, minyak goreng, dan coklat batang.

\section{e. Memberikan Informasi Kepada Masyarakat}

Setelah melakukan survei lokasi, percobaan atau pengembangan produk dan membuat desain kemasan, penulis melakukan koordinasi dengan tokoh masyarakat setempat bahwa ada produk inovasi baru yang akan di sosialisasikan untuk masyarakat banyak. Kemudian meminta izin untuk mengadakan demo atau sosialisasi terkait produk yang sudah dipersiapkan. Perizinan dilakukan kepada Ibu Lilis Ahmad selaku pemilik posko kelompok 1 dimana tempat tersebut dijadikan tempat untuk demo pelatihan. Pengumuman kepada masyarakat dilakukan sehari sebelum pelaksanaan demo pembuatan produk setelah melakukan perizinan. 


\section{3) Tahap Melaksanakan Solusi}

Dalam melaksanakan solusi dilakukan dengan Pelatihan produk pembuaatan churros dingkong dilaksanakan pada tanggal 28 Agustus 2019 dan 29 Agustus 2019. Pelatihan produksi produk ini dihadiri oleh ibu-ibu sekitaran Kp. Sirnagalih. Sebelum produksi produk churros dilaksanakan, penulis menyampaikan terlebih dahulu kepada ibu-ibu akan dibuat seperti apa singkong tersebut.

Produksi pembuatan churros singkong dilakukan dengan beberapa tahap seperti proses pengupasan, proses pencucian, proses pemotongan, proses pengukusan, proses pengolahan, proses pembentukan hingga proses pengemasan. Berikut proses pengolahan singkong:

1) Tahap pertama, proses pengupasan kulit dan pencucian singkong. Setelah proses pengupasan kulit singkong, dilakukan pencucian singkong untuk menghilangkan kotoran yang ada pada singkong.

2) Tahap kedua, proses pengukusan singkong. Setelah singkong bersih, selanjutnya singkong dikukus dalam pansi menggunakan api sedang. Bertujuan agar singkong dapat dihancurkan lebih mudah dan memudahkan saat proses pengolahan.

3) Tahap ketiga, proses pembuatan adonan churros. Pertama panaskan air, gula, dan mentega, setelah mendidih dan berbuih matikan kompor dan diamkan sebentar sampai uap panasnya hilang, setelah uap panasnya hilang masukan singkong yang sudah dihancurkan dan tepung terigu aduk rata sampai kalis sehingga membentuk adonan yang mudah dibentuk, diamkan sebentar sampai dingin lalu tahap terakhir adalah memasukan telur kedalam adonan tersebut aduk rata dan siap digoreng. Kemudian goreng hingga warnanya keemasan. Tahap selanjutnya hias churros dengan coklat yang sudah dicairkan agar terlihat lebih menari dan rasanya lebih enak.

Berikut proses pengolahan singkong menjadi Churros Singkong :

Bahan-bahan :

a. 300 gr singkong

b. 250 gr tepung terigu

c. 150 gr gula pasir

d. Sejumput garam

e. 2 sendok makan mentega

f. 2 butir telur

g. Air 2 gelas

h. Minyak goreng

i. Coklat batang berbagai warna

j. Gula halus

Cara Pembuatan:

a. Bersihkan dan potong kecil kecil singkong. 
b. Kukus singkong 10-15 menit hingga matang.

c. Kemudian hancurkan singkong dengan garpu sehingga berbentuk halus dan lembut.

d. Panaskan air kemudian masukan mentega, gula dan garam tunggu hingga mendidih.

e. Setelah mendidih matikan kompor, diamkan sebentar kemudian masukan singkong yang telah dihaluskan dan masukan terigu.

f. Aduk rata dan diamkan hingga uap panas menghilang.

g. Setelah dingin masukan telur dan aduk rata

h. Masukan adonan kedalam minyak yang sudah dipanaskan, goreng hingga kecoklatan

i. Kemudian dibalurkan toping coklat dan churros singkong siap dihidangkan.

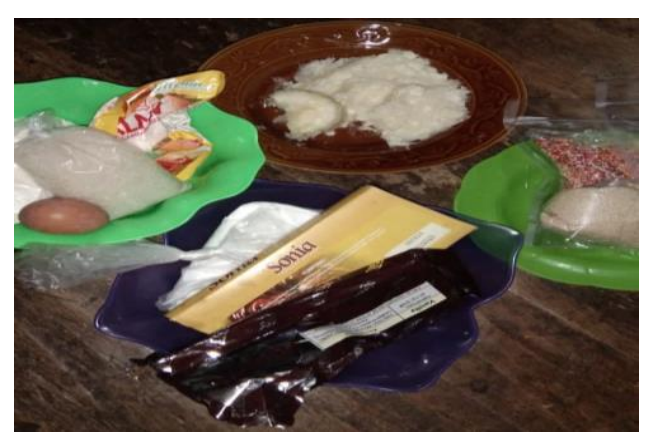

Gambar 2. Bahan-bahan pembuatan produk

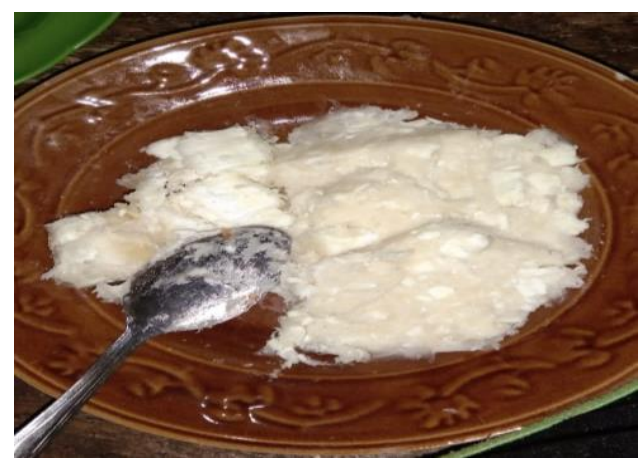

Gambar 3. Proses singkong dihancurkan

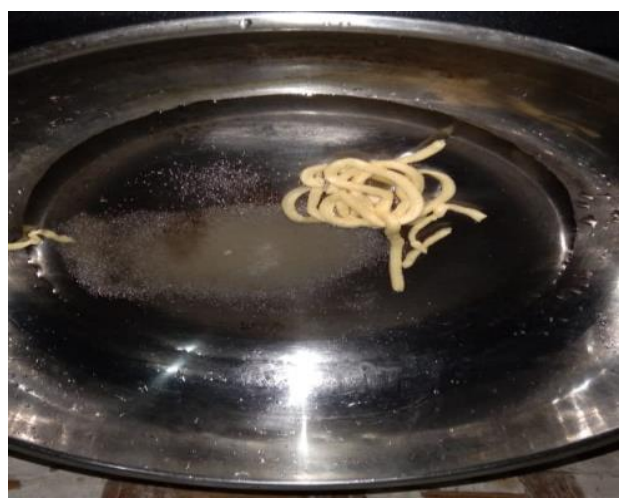

Gambar 4. Pemanasan air, mentega, dan gula 


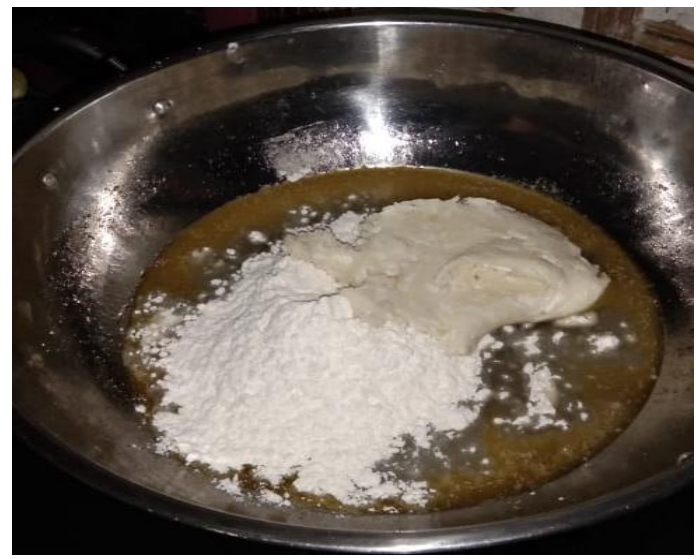

Gambar 5. Proses memasukkan singkong dan tepung

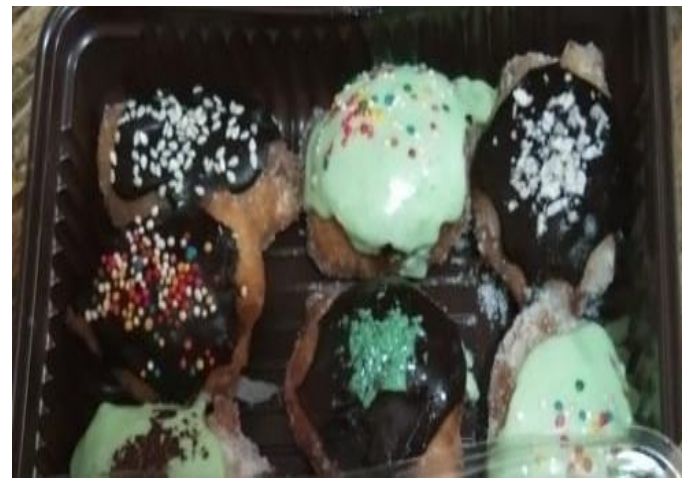

Gambar 6. Proses pemberian topping

\section{KESIMPULAN}

Perekonomian masyarakat Desa Padamulya masih perlu untuk ditingkatkan. Walaupun perekonomian masyarakat Desa Padamulya masih dapat dikatakan standar, tetapi tingkat perekonomian Desa Padamulya tersebut dapat ditingkatkan melalui kegiatan ekonomi kreatig melalui inovasi produk. Dapat dilihat dari segi geografis kampung Goleah berada pada kawasan yang stategis dikelilingi oleh beberapa taman hiburan keluarga seperti Curug Citambur, dan Wisata Pohon Pinus. Hal ini dapat dimanfaatkan untuk menggali potensi masyarakat di bidang ekonomi dan dengan adanya kegiatan pelatihan inovasi produk olahan singkong ini diharapkan dapat menjadi wadah bagi masyarakat untuk bisa memasarkannya sebagai sebuah oleh-oleh atau buah tangan khas Desa Padamulya. Setelah mengikuti kegiatan pelatihan pembuatan inovasi produk olahan singkong para ibu rumah tangga diharapkan bisa mencari celah bisnis yang ada dan dapat mengembangkannya sendiri di rumah masing-masing.

\section{DAFTAR PUSTAKA}

Aldy Purnomo, Rochmat. 2016. Ekonomi Kreatif Pilar Pembangunan Indonesia. Surakarta: Ziyad Visi Media. 
Ariyani, (2017). Pemanfaatan Kulit Singkong Sebagai Bahan Baku Arang Aktif Dengan Variasi Konsentrasi Naoh Dan Suh.

Hamali, Sambudi. (2016). Pengaruh Inovasi Terhadap Kinerja Bisnis Pada Industri Kecil Pakaian Jadi Kota Bandung.

Prasetyo, A. (2018). Potensi Peningkatan Produktivitas Kewirausahaan Berbasis Model Penguatan Teknopreneur pada Hasil Inovasi Kota Magelang. 